Research:

\title{
PNPB CREDIT MANAGEMENT AT THE MINISTRY OF ESDM
}

\author{
By: \\ SYARIEF GERALD PRASETYA \\ Lecturer at STIE Binaniaga Bogor
}

\begin{abstract}
State Non-taxable Revenue (PNBP) from the energy and mineral sources (ESDM) sectors, particularly at Oil and earth gas(Migas) sector, coal and mineral sector, are very significant revenue of the state which is State Non-taxable Revenue described on the National budget and revenue(APBN). Actually there are still a lot of BUMN, BUMD, private companies which have not paid yet their PNBP to the Ministry of ESDM.. This research aims to recognize empirically the system of PNBP management within the Ministry of ESDM. This research has applied an analytical descriptive method which is a method to provide an actual condition regarding the credit management. The State revenue refers to PNBP credit has still been beyond the expectation due to a slow process of PNBP credit administration as well as the organization management which has not been running well. An effort to speed up the process should have to be applied refers to the efficiency of the related sources consumed such as time, cost and manpower. An effort to develop the effectiveness of State credit administration should have to be applied by improving the organization performance to maximize the result of the State credit management.
\end{abstract}

\section{INTRODUCTION}

\section{Background of The Problem}

PNPB (State Non-taxable Revenue) at the energy and mineral resources sectors (minerba), particularly at oil and earth gas (migas), as well as coal and mineral (minerba) have been a significant value of the state revenue which is stated in the APBN (National expected revenue and spending) after the taxable revenue, thus, the management of this PNBP at ESDM sectors should have to be managed as effective and efficient as possible and have to be controlled as good as possible which is affecting to the increasing value of PNBP in the National Cash. Actually, there are still a lot of BUMN, BUMD, private companies that have not paid yet this PNBP to the Ministry of ESDM and it should have to be followed up and settled down, so that the target of the National Revenue could be achieved accordingly which is in compliance with APBN goal.

PNBP at ESDM sectors refers to the potential national revenue which could be developed by controlling PNBP more intensive such as, budgeting, target and revenue which is in compliance with the applicable regulations, as follows: Regulation No. 20 year 1997 regarding State Non-taxable revenue. Government Regulation no. 1 year 2004 regarding the Procedure of Planning and PNBP Realization Report. Government Regulation No. 22 year 2005 regarding PNBP evaluation and other related regulations.

Governing the National government is to achieve the government goals refers to the government's right and responsibility, including the management of the state credit. National finances management based on the Regulation No. 17 year 2003 regarding The National Monetary and Regulation No. 1 year 2004 regarding the State Treasury which have to be executed professionally, open, and full of responsibility for the sake of the wealthy of the people, which have been stated on the APBN and APBD. The biggest national revenue is from taxable revenues and non taxable revenues (PNBP) 


\section{Objectives}

This research aims to understand empirically the system of PNBP credit management at the Ministry of ESDM.

\section{LIBRARY REVIEW}

\section{State/National Non-taxable Revenue(PNBP).}

National Non-taxable Revenue (PNBP), based on the Regulation No. 20 chapter 1 article 1 year 1997 describing all the Central National Revenue refers to non-taxable revenue, as the following:
a. Receivable revenue which is from the government budget management .
b. Receivable revenue which is from natural resources consumption.
c. Receivable revenue which is from the State Treasury management allocated.
d. Receivable revenue which is from services activities performed by the government.
e. Receivable revenue which is from the administrative penalty decided by the court.
f. Receivable revenue which is from some grants as the government 's right, and
g. Other receivable revenue which is regulated in a separate regulation.

\section{Law Review refers to the State Credit Administration..}

Indonesia is a country based of law or "rechsstaat", instead of State of Power or "machsstaat', as stated on the the Indonesia Ideology stated on the 1945 Constitution (UUD 1945). The ideology refers to all the actions and attitude of the people of Indonesia in the society as well as in the country of Indonesia should have to respect the applicable regulations.

The aforementioned ideology is the basic idea in detemining the Acts no. 17 regarding The national financial. On the second paragraph, explaining about the general description of the related Acts, as follows:

"As a country which has been predominated by the people, based on laws, and has been governing the country based on the constitution, management system of the national finance ought to be in accordance with the regulations stipulated on the Constitution. In the Constituion of 1945 Chapter VIII regarding Finances, has stated that the national revenue and national spending have been determined every year based on the applicable regulations, and regarding taxes and other contributions which is obligatory related to the national needs and the currency hav been determined accordingly. Other national financial matter has been regulated in accordance with the Article 23C stipulated by the Laws."

The aforementioned basic idiology explains that the system of national financial management has been in compliance with the main rules stipulating in the Constitution of 1945. And the procedure to execute the system of national financial management has to be regulated by the Acts refers to the arrangement of the national credit.

The aforementioned explanation describes that the national credit administration should have to be based on a clear basic laws refers to any kind of related administration. Therefore, the administration of the national credit should have to respect to the applicable rules and regulation to minimize the possibility of regulations problems appeared during the process of the national credit administration.

\section{Comparison about the understanding of National Credit.}

The following table is the comparison betwen the understanding of the National Credit based on the Regulations No. 49 Prp year 1960 regarding the Committee of the National Credit Administration and the Regulations No. 1 year 2004 regarding The National Treasurer. 
Tabel 2.1.

Comparison about the National Credit Understanding.

\begin{tabular}{|c|c|c|c|}
\hline \multirow{2}{*}{ No. } & \multirow{2}{*}{ Description } & \multicolumn{2}{|c|}{ Based on } \\
\hline & & Regulation no. 49 Prp Year 1960 & Regulation No. 1 year 2004 \\
\hline 1. & Credit Definition & $\begin{array}{l}\text { Any kind of the credit that should have } \\
\text { to be paid by a person or an institution } \\
\text { to the state/government. }\end{array}$ & $\begin{array}{l}\text { a. A certain amount of money } \\
\text { that is obliged to be paid by a } \\
\text { person or an institution. } \\
\text { b. State's rights that could be } \\
\text { calculated as a certain amount } \\
\text { of money. }\end{array}$ \\
\hline 2. & $\begin{array}{l}\text { The reason why a } \\
\text { Credit has happened. }\end{array}$ & $\begin{array}{ll}\text { a. A contract agreement. } \\
\text { b. A regulation of } \\
\text { c. Other reasons }\end{array}$ & $\begin{array}{l}\text { a. A Contract Agreement } \\
\text { b. A regulation or } \\
\text { c. Other legal reasons. }\end{array}$ \\
\hline 3. & $\begin{array}{l}\text { The owner of the state's } \\
\text { credit }\end{array}$ & $\begin{array}{l}\text { a. Central Administration of the State } \\
\text { b. District Administration } \\
\text { c. National Business Unit } \\
\text { (BUMN)/District Business } \\
\text { Unit.(BUMD) } \\
\text { d. Subsidiary of BUMN/BUMD }\end{array}$ & Central Administration of the State. \\
\hline
\end{tabular}

Tabel 2.1 aforementioned has explained that the big differences of both of the understanding about the national credit refers to the differences about the ownership of the national credit. But, it still refers to the related applicable Regulations No. 40 Prp year 1960.

\section{Administration of the National Credit.}

The administration of the National Credit is still complying with the applicable regulation no. 49 Prp year 1960 regarding the Committee of the National Credit Affairs. Eventhough this regulation has only 15 articles but it has been regulating the whole subject, object and process of the national credit administration.

The process to administer the national credit was stipulated on the related regulation in order to obtain the fastest and the most effective result instead of going thru the Justice Office administration which would consume such a time (first level of the court, appealing to a higher court level, supreme court, judicial review).

In order to make the process more effective and faster, the person in charge to execute this national credit administration will be given a speciial authority named 'parate execution' is an authority to issue some statement letters which is having the same power as the judge's decision (in kracht van gewijsde) which is firm and powerful.

The effort to speed up and to make the administration of the national credit effective it has had its own objectives, but, when we learn about it carefully, refers to the purpose to save the national finance. The objectives are as follows;

a. The efforts to speed up the process of the national credit administration are focusing to consume the resources efficiently, time, cost and manpower. This efficiency efforts are only a part of the efforts to save the National financial.

b. The effort to increase the effectiveness of the National credit administration is to maximize the revenue of the National credit.

The aforementioned explanation has been describing that the efforts to speed up and to improve the effectiveness of the national credit administration are referring to the National Financial Security. It concludes that the National credit administration is a special process to save the national financial.

5. Institutions that could be able to perform the National Credit Admoiniostration Several institutions that are able to solve the credit problem, as follows:

a. State Court of Justice.

Regulation No. 4 year 2004 regarding the Judicial Authority regulating that the authority of the judicial affairs is executed by the Justice of the Supreme Court and the 
department of justice under it which is the coverage of judicial court refers to the general judicial court, religious court, military court, and national business administration court.

b. Office of the counsel for the prosecutor.

Based on the Article 30 point (2), Regulation no. 6 year 2004 regarding The Attorney of the Republic of Indonesia refers to civils case and national business administration, The attorney with their special authority could be able to conduct the execution either inside or outside of the court which is on behalf of the state or the government. Based on the aforementioned regulation, the role of the attorney in civils case is equal to the Government's Law Office or Advocates / lawyers of the state.

\section{c. Arbitration institution}

Solving the problem of the legal disputes thru the arbitration office is necessary acquired by any parties instead of the state court which would be time consuming to execution. This execution is in compliance with the regulations no. 30 year 1999 regarding the arbritration and the alternative administration to solve any legal dispute.

d. The National Bank Recovery Committee (BPPNN)

BPPN establishment is based on the Article 37A - regulation no. 10 year 1998 regarding the Changes of Regulations no. 7 year 1992 has stipulated that:

a) When Bank of Indonesia has encountered a lot of banks problems happened that could jeopardize the national economics, and upon the request of the Bank of Indonesia, the government after having been consulting with the Indonesian Legislative Assembly (DPR RI) could establish an ad hoc Committee to deal with banks recovery efforts.

b) The ad hoc committee will perform banks recovery program to the banks which have had problems refers to the list given by Bank of Indonesia. Such banks problems can jeopardize the national economics due to the condition of banking system which has been evaluated by Bank of Indonesia and stated as crises and lacked of people trustworthy which is affecting to the people life.

e. Committee of the National Credit Administration (PUPN)

Based on the regulation no, 49 Prp Year 1960, PUPN has to settle down the national credit refers to the list given by the government institutions and administrations. Therefore, based on the aforementioned regulation, PUPN has been authorized to solve the problems of credit crunch and is authorized to request the payment. PUPN and the debiturs has to provide a mutual agreement between them indicating the total amount of the credit and the payable installment payment agreed by the debiturs. This mutual agreement refers to the executorial authority has a strong power as strong as the judge's decision in civils disputes.

\section{RESEARCH METHOD}

\section{Research Method}

This research has been applying an analytical descriptive method, this study aims to provide an actual condition regarding Credit Arrangement.

\section{Data Collection method.}

a. Field research

Aims to obtain main data refers to primary data and secondary data of the credit which is affecting the credit happened. The related data either credit notes or data about the system of the credit arrangement at the ministry of ESDM which is still running.

Field research has been conducted by applying:

1) Observation.

By having been observing the actitivities or procedures related to the research study, as follows:

- $\quad$ Survey against the procedure of PNBP credit settlement.

- Study about the potential PNBP refers to the financial reports of the operator and regulator, credits classification of non-taxable national revenue (PNBP), credit administration unit, origin documentation refers to PNBP credits arrangement, 
2) Interview.

applicable forms or applicable list of PNBP credits, flow chart of PNBP credit arrangement, PNBP accountancy policiy.

Is a technique to collect the data by applying an interview with the people in the credit arrangement unit and people who have a direct contact with the credit management at the ministry of ESDM.

3) Library Research.

The activity to collect some data has been done by observing theoretically about some existing literatures, refers to the Regulations of the Republic of Indonesia No. 20 year 1997, Decree of the Minister of Monetary of the Republic of Indonesia No. 201/PMK.06/2010 and the National Accountancy Standard Declaration (PSAP) regarding PNBP credit, and other related literature. This data collection aims to obtain some secondary data as the basic of the theory relating to the credit management at the ministry of ESDM.

4) Sampling technique.

This sampling technique has been applying a purposive sampling technique to obtain the related samples which is in accordance with the objective of this research.

\section{Data Analysis Technique}

Descriptive analysis is the evaluation about providing PNBP credit in the Financial Report whether it has been categorized according to the Standard of PSAP providing.

\section{EXPLANATION}

\section{Credit}

A Credit is an asset which is one of the most important post in the Balance sheet and when it meets a due date of the settlement,then requested payment will happen and will be an additional asset at the cut off period of the financial report. According to PMK No. 201 on Chapter I Article 1, credit means a certain amount of money to be paid to the National Ministry I Administration refers to the agreement or other reasons based on the applicable regulation or other legal administrations.

Credit transaction has occured due to two categories of revenue.

First, Revenue obtained from the exchange transaction refers to the entity that receives the goods and services or elicits a credit deduction by determining the same value or almost the same value refers to goods, services or application of the entity assets.

example; purchasing - selling transactions of goods and services.

Second, revenue which is non exchange transaction refers to a receivable revenue due to the authority power, eq, direct-taxable or indirect taxable, stamps, penalty, contribution and donation.

Credits description in the balance sheet is regulated by the paragraph 43 PSAP 01, determined that balance sheet should have to identify at least cost centres of taxable credit and non taxable credit.

Non taxable credit is due to the exchange transaction and non-exchange transaction occured refers to the National Non-Taxable Revenue (PNBP). PNBP means all receivable revenue of the Central State which is non-taxable revenue and other credit.

Classification of PNBP credit are as follows:

a. Credit from natural resources revenue consisting of:

- Natural Pretroleum .

- Natural gas.

- General mining.

- Forestry.

- Fishery affairs.

b. Credit from BUMN profits consisting of :

- $\quad$ BUMN profits belongs to the state.

c. Credits from other BNBP revenues consisting of:

- $\quad$ Selling, renting and servicing. 
- Attorney, judicial affairs.

- Educations.

- Other revenues.

\section{Internal Control}

The system of internal control of PNBP credit has applied a system to distinguish nonpayable credit. This distinguished non-payable credit which is at the National Ministry I Departments should have to be executed very carefully. Due to the careful execution, thus, the Minister/ Chief of the Administration should have :

- $\quad$ to evaluate the credit quality / ranking.

- to control and to take a necessary action refers to the distinguished non-payable credit to make it happen.

The evaluation of the credit quality / ranking should have to consider, at least:

- $\quad$ Due date of the credit.

- Efforts to get the payment.

Any of the National Ministry or Administration that has not been applying the internal control system will get a written warning from the Ministry of Finance. The evaluation of PNBP credit quality / ranking is based on the credit condition by the time of the date of the Financial Report. The classification of PNBP credit quality / ranking has been determined based on:

a. Good payable credit ranking when the payment has been settled accordingly refers to the due date of the invoice.

b. Poor payable credit ranking when the payment has not been settled within one month after the due date of the invoice.

c. Doubtfull payable credit ranking when the payment has not been settled within one month after the due date of the second invoice as reminder the second.

d. Credit Crunch when :

- The payment has not been settled within one month after the due date of the third invoice as reminder the third, or

- The related credit has been distributed to the National Credit Affairs / Directorate General of National Treasury

Furthermore, the regulation to distinguish the PNBP credit is obliged to be done by the National Ministry or Administrations are as follows:

a. 5\% against the PNBP credit amount which is at a good payable credit ranking

b. $10 \%$ against the credit amount calculated after being reduced by the value of the guarantee goods or confiscated goods which is at poor payable credit ranking.

c. 50\% against the credit amount calculated after being reduced by the value of the guarantee goods or confiscated goods which is at a doubtfull payable credit ranking.

d. $100 \%$ against the credit amount calculated after being reduced by the value of the guarantee goods or confiscated goods which is at a credit crunch level.

The value of guarantee goods has been calculated and determined as a reducing account being applied to distinguish the unpayable credit, defined as follows :

a. $100 \%$ against the guarantee goods value refers to valuable certificates issued by Bank of Indonesia, States valuable letters, bank guarantee, savings and fixed deposit that have been blocked by the bank, gold and other precious metal.

b. $80 \%$ against the guarantee value of land ownership certificate or land development certificate (SHGB) along with the related buildings on it.

c. $60 \%$ against the taxable selling value of land ownership certificate (SHM), Land Development or usable land Certificate (SHGB) together with the buildings on it which is free from the guarantee rights.

d. $50 \%$ against the taxable selling value upon a legal tradional letter of land ownership(Letter C) or any non certificate but legal ownership of the land paper which is attached by SPPT (tax payment declaration letter).

e. $50 \%$ against the mortage value of the aeroplanes and sea-ships which is 20 cubic meter at the minimum. 
f. $50 \%$ against the guarantee value refers to the depreciation value of the automotive vehicles, and

g. 50\% against the value of the aeroplanes, seaships, automotive vehicles completed with the related legal letter of the ownership which is free from the agreement and is in compliance with the applicable regulations.

The guarantee goods as mentioned on a to $\mathrm{g}$ points aforementioned could be considered as a reducing factors to distinguish unpayable credit after having been approved by the Ministry of Finance.

Furthermore, the value of confiscated goods which is considered as a reducing factor to distinguish the unpayable credit has been defined as follows:

a. $100 \%$ against guarantee goods refer to a valuable certificate letters issued by Bank of Indonesia, national guarantee letter, savings and deposits which have been blocked by the banks, gold and other precious metal.

b. $60 \%$ against the selling value of land ownership certificate (SHM) and authorized land development certificate (SHGB) along with the buildings established on it.

C. 50\% against the taxable selling value of the tradional ownership land letter (letter C) or the ownership of the land non certificate completed with a recent SPPT (Taxable Declaration Letter), and

d. 50\% against the value of aeroplanes, sea-ships, automotive vehicles completed with the related ownership certificate.

Confiscated goods as mentioned on a to d points aforementioned are not considered as reducing factors in the distinguished non-payable credit.

Credit Restructure Policy could be applied by the National Ministry or Administration to the debitur refers to the credit rank, as follows:

a. Upgrade doubtful credit payable level or credit crunch level to poor credit payable ranking / level.

b. No changes when the credit payable rank is at poor credit rank.

Credit elimination against the remaining credit payable could be given by the National Ministry / Administration to the related debitur which is suffering a credit crunch accordingly refers to the applicable regulations. Credit elimination refers to reducing the credit account and the distinguished non payable credit account amounting to the total described on the related statement letter.

\section{Arrangement and organization of PNBP credit.}

A credit transaction could be identified and noted as the payment being able to increase the national net wealth properties when the system of PNBP credit arrangement is understandable and in compliance with SAP (SOP).

This PNBP credit arrangement could be defined as the documentation process of financial reporting which is the government property refers to a certain amount of money, goods, services based on the applicable regulations.

The objectives of PNBP credit arrangement system which is in accordance with the SAP are as follows;

- is able to provide an accurate information and on schedule.

- to protect the PNBP credit transaction by recording, processing and financial transaction reporting consistently.

- to support PSAP application to obtain PNBP credit information as the basic of taking responsibility and decision making.

To recognize whether the internal controlling system of PNBP credit has been running well refers to the system of PNBP credit arrangement which is in compliance with PSAP, PP, PMK and other regulations.

Documentation related to PNBP credit arrangement are as follows:

1. Contract agreement of PNBP credit.

2. Statement letter of PNBP credit, legal letter of full responsibility. (SKTJM / SKTM)

3. Receipt of non taxable payment and other payment receipt.

4. Legal Statement Letter to eliminate the credit.

5. Other documentation related to PNBP credit.

Related Forms and List refers to PNBP credit arrangement.

1. Credit Records. 
Is a record describing the total amount of the credit, credit mutation and credit balance of every debitur.

2. List of Credit Recapitulation.

Is a list mentioning the total amount of the credit mutation and credit balance based on the type of the related credit.

3. List of Credit Balance.

Is a list describing the credit balance based on the recapitulation of each credit in semester period.

4. List of the credit life time.

Is a list describing the classification of the credit which has not been paid (over the due date) based on the credit time-line which is reporting provided end of the years.

5. List of the Credit Balance Reclassification.

Is a list determining the payable account and poor payable account. Reclassifying the poor payable assets to be into the payable assets has been defined due to the total amount and the time line of the credit which is within 12 months will be due date refers to the date in the balance statement.

6. Assets Journal Forms.

Is a form to record all the additional and reduction of the assets value which is in the balance sheet.

Application of the aforementioned documentation, list and forms could be recognized at the flowchart of PNBP credit arrangement herebelow.

System of PNBP credit arrangement has been described as the following diagram

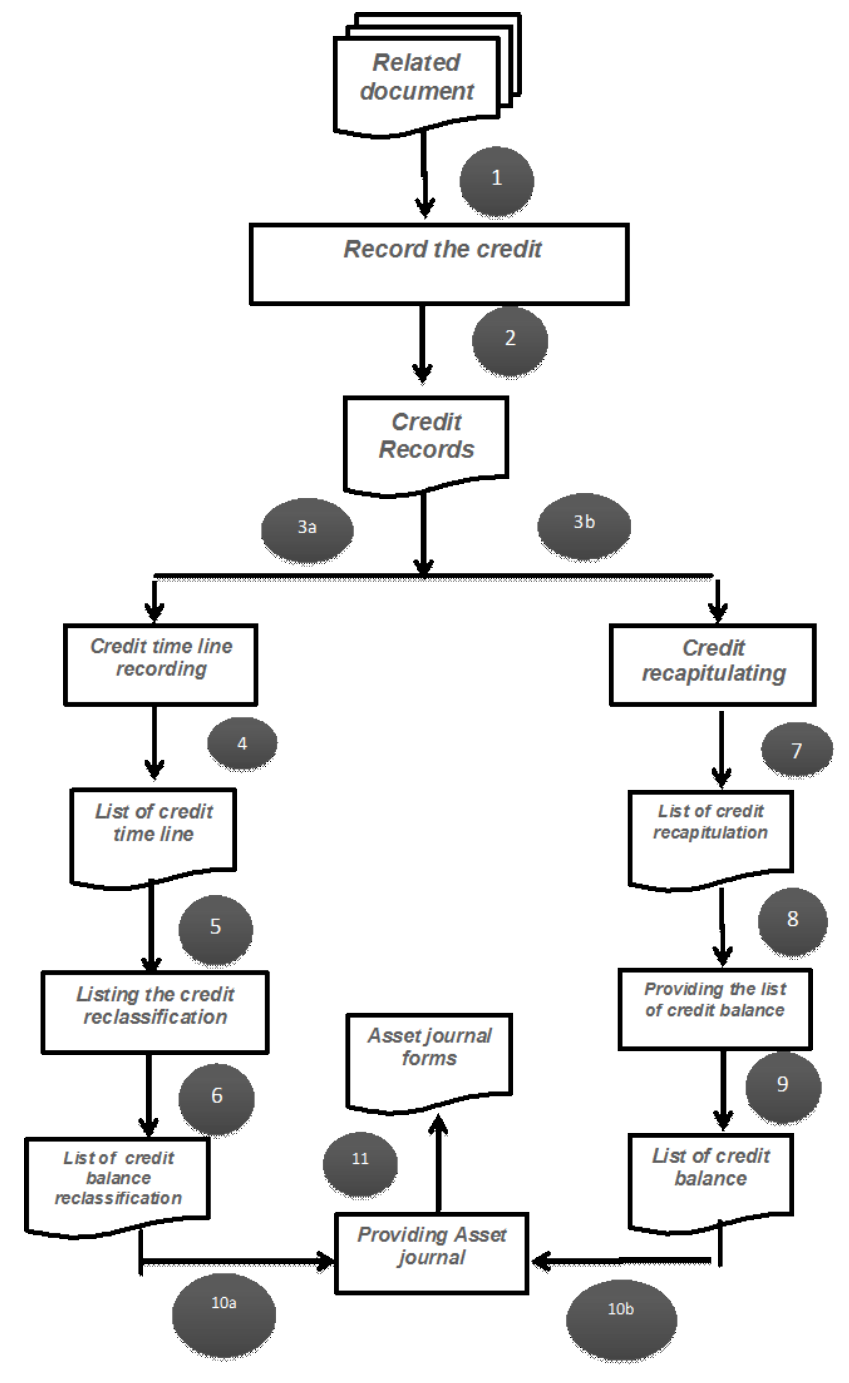

Syarief Gerald Prasetya: PNPB Credit Management at the Ministry of ESDM

Page: 52 
Tabel 4.1

Explanation about PNBP credit arrangement diagram

\begin{tabular}{|c|l|}
\hline Nomor & \multicolumn{1}{c|}{ Descriptions } \\
\hline $1-2$ & $\begin{array}{l}\text { Credit arrangement officer -to receive and to record the related document } \\
\text { in to the credit cards. }\end{array}$ \\
\hline $3 a-3 b$ & $\begin{array}{l}\text { Credit arrangement officer - to record the credit time line and to perform } \\
\text { the credit recapitulation based on the credit record. }\end{array}$ \\
\hline $4-6$ & $\begin{array}{l}\text { Credit Arrangement Officer - to make a list about credit balance } \\
\text { recapitulation based on the time line of the credit. }\end{array}$ \\
\hline $7-9$ & $\begin{array}{l}\text { Credit Arrangement Officer - to provide the credit balance statement } \\
\text { based on the list of credit recapitulation. }\end{array}$ \\
\hline $10-11$ & $\begin{array}{l}\text { Credit Accountancy Officer - to provilde journal asset based on the list of } \\
\text { credit recapitulation and list of credit balance statement received from the } \\
\text { credit arrangement officer. }\end{array}$ \\
\hline
\end{tabular}

\section{Accountancy Policy of PNBP credit}

Accountancy Policy of PNBP Credit has applied three main subjects, as follows: 1) PNBP Credit Declaration; 2) PNBP Credit Measurement; 3) PNBP Credit Disclosure.

1. PNBP Credit Declaration

- Non-taxable Credit which has not been paid yet at the due date of the balance statement should have to be notified as PNBP credit in the balance statement.

- Payable Sales Installment Invoice (TPA) is accepted at the end of the years by reclassifying the TPA which is close to the due date of the invoice at the following year refers to the date of the balance statement itself. This reclassifying credit will reduce the account of TPA in the balance statement.

- Payable Financial Losses Demand (TGR) is accepted at the end of the year by reclassifying a long time line of TGR which is close to a due date of the payment at the following year based on the date of the balance statement. This reclassifying credit will reduce the account of TGR in the balance statement.

- Other Non-taxable Credit could be accepted on the issuance date of PNBP credit declaration.

- Payable credit unit will transfer the payment to BUMN / BUMD / District Administration, and Foreign Administration refers to the due date of the payment at the following year based on the date on the balance statement. The aforementioned reclassifying will reduce the account of the creditor notified in the balance sheet.

2. PNBP Credit Measurement.

- Non-taxable credit has been recorded based on the total amount of the invoice which has not been paid by the debitur refers to the date of the balance statement.

- Recorded payable TPA based on the nominal total amount in rupiah that will be received within one year.

- Recorded payable TGR based on the nominal total amount in rupiah that will be received within one year.

- Payable credit transfered to BUMN / BUMD / District Administration and Foreign Administration based on the nominal total amount of the payable credit in rupiah.

- Other Non-taxable credit has been recorded based on the nominal total amount in rupiah refers to the settlement which has not been paid yet.

3. PNBP Credit Declaration

PNBP credit is notified as payable asset in the balance statement and is disclosed in CALK (Notification on the Financial Report), such as:

- Credit type in details.

- Explanation about credit settlement which remains at the National Ministry I Administration or it has been sent to DJKN.

- Explanation about a credit as the result of TPA and / or TGR reclassification.

- Explanation about a credit as the result of Credit Loan reclassification sent to BUMN / BUMD / District Administration, and foreign administration. 
- Explanation about other non-taxable credit.

- $\quad$ List of PNBP credit time line.

\section{Accountancy of PNBP Credit.}

Notification of PNBP credit has been recorded on the Organization Structure of Financial Bureau at the Treasury Department and Accountancy Department by the credit accountancy officer refers to budget user authority level. Credit accountancy officer periodically has recorded PNBP credit owned by the Budget User Authority based on the credit records. This recording has only been done at the opening balance statement of a credit and would be added and reducred end of the semester. End of the year, PNBP credt reclassification would be done. This PNBP credit reclassification would be executed at the end and beginning of the following year to provide a reverse journal.

\section{Objects and PNBP Credit type.}

The estimation of PNBP Migas and Minerbapum credit at the Ministry of ESDM is created based on the national non-taxable revenue at the Ministry of ESDM itself. The National non-taxable Revenue of Migas and Minerbapum at the Ministry of ESDM has been considered as the central national revenue being classified into three types of revenue and one of them is the National Noln-taxable Revenue (PNBP).

PNBP is regulated in the Regulation No. 20 year 1997 regarding PNBP, based on this regulation, hence, the Ministry of ESDM Eselon I Directorate Generale of Migas and Ditjen Minerbapabum have been allocating such a revenue which should have to be received within the year of Financial Budget at the Ministry of ESDM. Obviously, the declaration of accountancy revenue at the Ditjen Migas and Minerbapabum based on PP no. 24 year 2005 regarding the National Accountancy Standard, based on Cash toward accrual, it explains that the receivable and spendable revenue will be confirmed as soon as the receiving or spending national cash account occurred which is affecting the net national properties, therefore all the revenue received by the treasurer should have to be transferred to the National General Cash account, but, when it has not been transferred yet to the national cash account, then it should have to be recorded as a cash at the treasurer refers to the revenue of the Ministry of ESDM in the balance statement. PNBP credit which is appearing in the Ministry or Administration at the end of the related year based on the PNBP statement letter or other legal document refers to the invoice which has not been settled completely. PNBP credit recorded at the Ministry of ESDM has been stipulated in the APBN refers to:

a. The Revenue of Natural Resources, Natural petroleum, natural gas, general mining, forestry, fishery, natural energy mining.

b. Revenue of BUMN profit, revenue of BUMN profit owned by the government.

c. Other PNBP revenue refers to sales and rental, services, bank interests, attorney and yudicial, education, gratification and confiscated money due to corruptions, penalty fine and contribution, and others.

PNBP credit appeared due to some agreements occurring between the Ministry of ESDM and other parties refers to loan, sales and purchase, services provider, partnership, and others. PNBP business credit at Migas and Minerbapum has been appeared due to unpayable payment refers to PNBP Migas and Minerbapum group business such as, sales revenue, services revenue, attorney and judicial revenue, and other revenue

\section{PNBP Credit Arrangement Unit.}

A Credit Arrangement Unit can be a structural unit or officer depends on the size of the organization and the transaction being occurred. Taxable Credit Arrangement Unit is a unit at the Directorate General of Tax.

Non-taxable payable of Credit Arrangment Unit, payable of the installment sales payment, payable of the financial losses substitution, payable of permanent investment, other non-taxable credit at the National Ministry / Administration should have been in compliance with the related organization structure. Credit Arrangement Unit at the National Ministry I Administration has been involving the operational unit, the administrative unit supporting the credit accountancy functions, and book keeping unit at the operational unit. The operational unit is a unit / organization that has been managing the national revenue within the related institution.

This operational unit has been operating the following tasks: 
1. To issue a credit declaration letter.

2. To issue a credit invoice.

3. To distribute the invoices to the administration officer and bookkeeping officer.

4. To issue a letter about transferring the unpayable payment and application letter to the Directorate Generale of Credit and National Auction Department of Finance to execute the related non-payable invoices.

5. To prepare a letter of recommendation to eliminate the credit.

6. To file the credit documentation.

An Administration unit is a unit / officer that will deliver and receive the credit documents, as follows:

1. Receiving the credit documents / invoices.

2. To schedule the incoming or the outgoing letter/documents from or to the debiturs (Debiturs are the persons / organizations that are obliged to conduct the loan payment to the government which is regulated within the contract and based on the related regulation).

3. To issue the covering letters.

4. To distribute the feed back documents from debiturs to the operational unit / officer.

5. Sending the receipt of payment to the bookkeeping unit.

Bookkeeping unit is a unit / organization that has been providing the related bookkeeping and credit reports. This unit has been;

1. recording all the credit into the credit card / record based on the related transaction documents.

2. providing the list of credit recapitulation.

3. providing the list of the credit time line and credit reclassification.

4. providing the list of the credit balance quarterly based on the credit records.

5. performing the archiving.

6. Sending all the reports.

Relationship among the credit arrangement units could be explained according to the following flow of diagram;

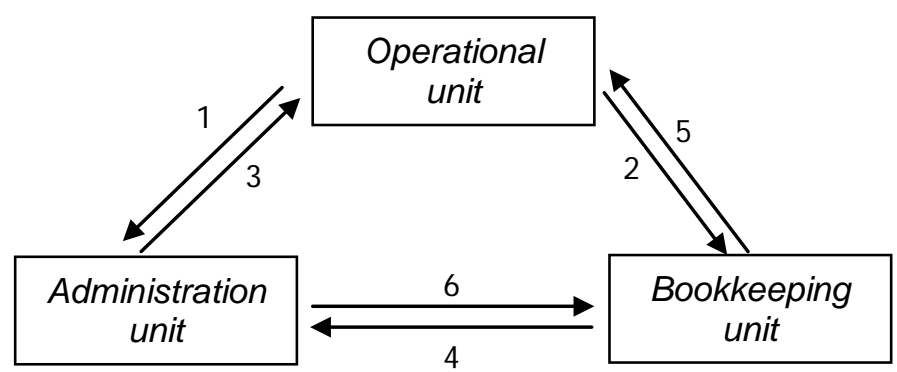

Drawing 4.2

Credit Arrangement Unit.

Descriptions about the aforementioned drawing are as follows;

1. Sending the invoice to the debitur thru the administration unit in order to obtain a feed back letter.

2. Sending the documents / credit invoice to the bookkeeping unit to be recorded.

3. Sending a feed-back letter from the debitur to the administration unit.

4. distributing receipt of the payment to bookkeeping unit.

5. providing the credit reports based on the credit type.

6. Distributing the related credit reports to the superior person in charge at the accountancy unit.

\section{Related Sources Document.} follows:

Related sources documents that will be the sources of PNBP credit arrangement are as

1. PNBP credit contract agreement. 
2. Statement letters related to PNBP credit, appointed full responsible and authorized person. (SKTJM / SKTM).

3. Receipts of non-taxable payment and other payment

4. Abolition /elimination the credit Statement Letter.

5. Other documents related to PNBP credits.

9. PNBP Credit Arrangement by the credit accountancy officer / unit.

PNBP credit arrangement is the process of recording and reporting about a certain amount of money which is the property of the government or other obligation to be performed by other party to the government refers to money distribution, goods and services done by the government or other reasons happened based on the applicable regulations.

Forms / list being used to record the related credit, as follows:

1. Credit Record Card.

Is a record card describing such amount of credit, mutation and credit balance of every debitur. Credit recording has to be done because of the government/national right / property that should have to be settled or other obligation that should have to be completed by other party to the government. This recording is based on the related document refers to the credit statement letter, payment receipt and credit abolition letter. Credit records should have to be completed every time when the transaction has happened.

2. List of Credit Recapitulation.

Is a list describing the total amount of the mutation and credit balance accordingly based on the type of the credit. This record has to be provided every semester which is in accordance with the mutation defined on the credit form.

3. List of Credit Balance.

is a list describing a credit balance based on the recapitulation of the credit type and to be provided every semester accordingly.

4. List of Credit Time Line / life time

Is a list defining the classification of the unpayable credit (over the time limit of the credit) based on the credit time line and should have to be provided at end of the years.

5. List of the reclassification.

In order to ease the credit reclassification, hence, the list of credit balance classification should have to be provided to explain the payable account and unpayable account. Reclassification of non payable asset moved to payable asset because the amount will be due date within 12 months from the date of the balance statement. Format of the list of the reclassification and the guideline to perform it could be seen on the page of 22 Attachment of the Regulation of the Director General of Treasury.

6. Form of Asset Journal (FJA).

Is a form could be used to record any additional, reduction and abolition of the asset value notified on the balance statement which is a credit asset value on the balance statement.

\section{CONCLUSION AND SUGGESTIONS}

\section{Conclusion}

1. Non-taxable credit has appeared because the exchange transaction and non exchange transaction have been treated as credit refers to the National Revenue non-taxable.

2. PNBP of functional revenue should have to be re-examined regarding the tariff amount which is too low comparing to the value of the services obtained for example, tariff of office house rental, tariff of 'leges' money, etc.

3. Refers to PNBP of the natural resources, PNBP tariffs should have to be more flexible, means, the tariffs should have to be evaluated regularly. When the price of commodity goods are increasing then the related tariffs should have to be increased too, so that the national revenue will be able to be developed accordingly.

4. National revenue received from PNBP credit is quite low due to the slow process of the administration and the organization arrangement has not been running quite well. 


\section{Suggestions}

1. National credit administration should have to be applied based on a clear legal regulation.

2. National credit administration should have to be refered to the related applicable regulations to minimize any possibility legal problems occured during the administration process of the national credit.

3. An effort to speed up the national administration process should have to be applied in order to be able to consume the resources efficiently refers to time, cost and manpower.

4. An effort to develop the effectiveness of the national credit administration should have to be applied to maximize the national credit revenue.

\section{REFERENCE}

Baridwan Z. Intermediate Accounting Edisi Ketujuh. Penerbit BPFE UGM, Jogjakarta. 1997.

Fess, et.all. Accounting $8^{\text {th }}$ Edition. South Western College Publishing. 1995.

Harahap S,S. Analisa Kritis Atas Laporan Keuangan Edisi Satu. Penerbit Raja Grafindo Persada, Jakarta. 1998.

Helfert. Technique of Financial Analysis, Terjemahan Herman Wibowo, Analsis Laporan Keuangan Edisi Ketujuh. Penerbit Erlangga, Jakarta. 1993.

Ikatan Akuntan Indonesia. Standar Akuntansi Keuangan Buku Satu. Penerbit Salemba Empat, Jakarta. 1995.

Munawir. Analisa Laporan Keuangan. Edisi Empat. Penerbit Liberty, Jogjakarta. 1990.

Sartono ,A,R. Manajemen Keuangan : Teori dan Aplikasi. BPFE, Jogjakarta. 2000.

Sundjaja RS dan Barlian I. Manajemen Keuangan. Satu Edisi Keempat. PT. Prenhallindo, Jakarta. 2002

Other Reference:

Peraturan Menteri Keuangan (PMK) No 201 tahun 2010 tentang Kualitas Piutang Kementerian Negara/Lembaga Dan Pembentukan Penyisihan piutang Tidak Tertagih.

Buletin Teknis Standar Akuntansi Pemerintah No 06 Akuntansi Piutang (Komite Standar Akuntansi Pemerintahan).

PSAP 01 tentang Penyajian Laporan Keuangan.

UU No. 20 tahun 1997 tentang Penerimaan Negara Bukan Pajak.

Pedoman Penatausahaan dan Akuntansi Piutang PNBP (PERDIRJEN 02 / 2007). 
The Accounting Journal of BINANIAGA Vol. 01, No. 1, 2016

ISSN: 2527 - 4309

This page intentionally be emptied.

Syarief Gerald Prasetya: PNPB Credit Management at the Ministry of ESDM

Page: 58 